\title{
The association between graduates' field of study and occupational attainment in West Germany, 1980-2008
}

\author{
Markus Klein'1
}

Published online: 18 May 2016

(C) The Author(s) 2016. This article is available at SpringerLink with Open Access

\begin{abstract}
Over the course of higher education expansion and growing numbers of graduates, employers are supposed to have increasing difficulties to regard a higher education degree as reliable signal for productivity. As a consequence, they may take into account 'qualitative' differences such as graduates' field of study more often than in previous times when hiring labour market entrants. Both from a supply- and demand-side perspective graduates from humanities, social services or arts may be increasingly disadvantaged in terms of labour market outcomes compared to graduates from science, technology, engineering and mathematics over time. The article tests this argumentation by assessing changes in the relationship between graduates' field of study and risk of unemployment as well as access to the service class in West Germany between 1980 and 2008. Changes in returns to field of study may contribute to growing (social) inequalities among graduates amidst educational expansion and are therefore important to consider. Based on Microcensus data, the results show that field of study differences in terms of both labour market outcomes did not increasingly diverge over time. The paper concludes that due to a limited educational expansion and the prevalence of an occupationally segmented labour market higher education remains a good investment in terms of labour market returns in West Germany irrespective of graduates' field of study.
\end{abstract}

Keywords Field of study · Higher education - Educational Expansion · Returns to Education · Germany

Markus Klein

markus.klein@strath.ac.uk

1 School of Education, University of Strathclyde, 141 St James Road, Glasgow, G4 OLT, UK

\section{Der Zusammenhang zwischen Studienfach und beruflichem Erfolg von Hochschulabsolventen in Westdeutschland}

Zusammenfassung Angesichts der Bildungsexpansion und der steigenden Zahl an Hochschulabsolventen erweist es sich für Arbeitgeber zunehmend als schwierig, einen Hochschulabschluss noch als zuverlässiges Signal für die Produktivität der Bewerber zu deuten. Eine These lautet daher, dass Arbeitgeber bei der Einstellung von Arbeitsmarktanfängern nunmehr verstärkt auf qualitative Unterschiede achten, etwa das Studienfach der Hochschulabsolventen. Demnach könnten Absolventen der Geistesund Sozialwissenschaften künftig sowohl angebots- als auch nachfrageseitig gegenüber Absolventen aus den Natur- und Ingenieurswissenschaften und der Mathematik mit Blick auf deren Arbeitsmarktchancen zunehmend benachteiligt sein. Dieser Artikel überprüft dieses Argument, indem er die Veränderung des Zusammenhangs zwischen dem Studienfach der Absolventen und deren Arbeitslosigkeitsrisiko sowie deren Zugang zur Dienstklasse (service class) in Westdeutschland für den Zeitraum von 1980 und 2008 untersucht. Veränderungen in den fachspezifischen Bildungsrenditen könnten demnach trotz des Ausbaus der Hochschulbildung zu steigender (sozialer) Ungleichheit zwischen Hochschulabsolventen führen. Die Ergebnisse, die auf Basis der Mikrozensusdaten erhoben wurden, zeigen, dass sich im Laufe der Zeit die Unterschiede zwischen den Studienfächern und den beiden Indikatoren für deren Arbeitsmarktperformanz nicht signifikant geändert haben. Insgesamt zeigt sich, dass Hochschulbildung in Westdeutschland angesichts der bislang begrenzten Bildungsexpansion und des stark segmentierten Arbeitsmarktes weiterhin eine gute Investition darstellt - unabhängig vom gewählten Studienfach. 


\section{Introduction}

The literature on social stratification increasingly paid attention to the impact of horizontal differentiations in postsecondary education on occupational attainment or earnings (for an overview see Gerber and Cheung 2008). Among these horizontal differentiations, the field of study is regarded as one of the key determinants of socio-economic inequality. Initial research in the US primarily looked at the mediating role of college major for the gender wage gap (e. g. Bobbitt-Zeher 2007; Brown and Corcoran 1997; Daymont and Andrisani 1984; Gerhart 1990). Further studies addressed the question why fields of study differ in labour market outcomes and associate these differences with specialization effects (Van de Werfhorst and Kraaykamp 2001; Klein 2011a; Paglin and Rufolo 1990; Shauman 2006) or stress the mediating role of job characteristics (Roksa 2005; Wolbers 2003). Other research was concerned with cross-national comparisons and how the institutional context shapes the association between fields of study and a variety of labour market outcomes (e.g. Giesecke and Schindler 2008; Kim and Kim 2003; Reimer and Steinmetz 2009; Van de Werfhorst 2004).

Despite this vast literature, changes in the association between graduates' field of study and labour market returns across time have been rarely investigated (for an exception see Gerber and Schaefer 2004 on Russia). Due to changes on the supply-side, i. e. educational expansion and on the demand-side, i. e. occupational upgrading and technological changes returns to different fields of study cannot be assumed to remain constant across periods. Changes in the labour market value of fields of study are consequential for trends in socio-economic inequalities and intergenerational social mobility. During educational expansion children from higher social background may increasingly feel the need to differentiate themselves from children from lower social background by choosing more frequently fields of study that involve higher rewards in the labour market (see "effectively maintained inequality" hypothesis, Lucas 2001). If these rewarding fields become more beneficial in terms of labour market outcomes over time compared to less rewarding fields, this development contributes to a widening socio-economic gap among graduates.

Both from a supply- and demand-side perspective there are reasons to argue that graduates' field of study has become more important in job allocation procedures over time. From a signalling perspective (Spence 1973), higher education qualifications may increasingly lose their signalling capacity in terms of potential productivity if more and more students are able to attain a degree in the course of higher education expansion. Employers may therefore take other observable indicators such as qualitative differences (field of study, higher education institution, final grade) into account in order to differentiate between graduates in their hiring decisions. When higher education degrees become increasingly more unreliable during higher education expansion, employers are supposed to increasingly use graduates' field of study as selection criterion (Hansen; Jackson et al. 2005; Van de Werfhorst 2002). Reimer et al. (2008) suggest that amidst educational expansion increasingly untalented students would gain access to higher education and opt for the less academically challenging fields like humanities or social sciences, rather than STEM (science, technology, engineering and mathematics) fields. As a consequence, the signalling value of less demanding fields in the labour market would decline. The authors provide some support for their hypothesis: the higher the proportion of tertiary graduates in a country, the higher the relative unemployment risk for graduates from humanities.

From a demand-side perspective, amidst an increasing demand for high-skilled labour due to technological changes some fields of study may have more substantially profited from these occupational changes in terms of availability of appropriate graduate jobs than others. During occupational upgrading in West Germany administrative and managerial positions as well as technical expert positions have expanded more strongly than positions in social and cultural services (Klein 2011b). Some field of study groups (STEM fields, business) may have benefited from these compositional changes more than others (humanities, arts, social work) in terms of occupational attainment.

This article contributes to the literature by assessing changes in the relationship between graduates' field of study and labour market outcomes (risk of unemployment, access to service class positions) over time in West Germany. For the analysis I make use of a long series of largescale German labour force surveys (Microcensus) between 1980 and 2008.

In the following, I present theoretical considerations on the relationship between field of study and labour market outcomes and its potential changes over time. Thereafter, I introduce the data and methods before showing the results. The article concludes with a discussion of the results.

\section{Theoretical considerations}

\subsection{Educational expansion and compositional changes in the recruitment pool}

From a human capital perspective, graduates from different fields of study acquire different competencies and skills during their studies (e.g. Van de Werfhorst and Kraaykamp 2001). Fields of study may differ in the provision of general academic skills, learning environments, the complexity of curricula or mathematical skills that are assumed to be 
scarcer than other skills in the graduate population (Paglin and Rufolo 1990). Thus, some fields may provide students with more challenging and productive skills and knowledge than others.

Whether the acquisition of human capital during studies is rewarded in the labour market may depend on the demand for specific skills (Heijke et al. 2003). Some fields of study may produce more job-related skills and prepare students for specific occupations or occupational segments, whereas others mostly convey general skills and lack an occupational specific orientation (Noelke et al. 2012). Since job applicants that match the skill requirements of the job are more productive and require less training, they may have advantages in labour market returns over graduates from fields of study that rather convey general skills (Glebbeek et al. 1989).

In contrast to human capital theory, the signalling theory (Spence 1973; Stiglitz 1975) drops the unrealistic assumption of perfect information with regard to individuals' potential productivity. Employers have to rely on imperfect information and hire job applicants in uncertainty about their true productivity. Aside from the educational level employers use the field of study as signal for potential productivity. They rank graduates from different fields of study into a labour queue according to potential training costs and match it to a second queue of vacant jobs sorted by skill requirements (Thurow 1975). If students are able to complete the most challenging fields, they indicate lower training costs in the future and have a higher probability of fulfilling the requirements of a demanding job.

From a strict signalling perspective, one's field of study may not indicate a different acquisition of skills but rather signal differences in the graduate population in terms of pre-existing cognitive abilities, motivation or commitment (Davies and Guppy 1997; Ishida et al. 1997). The most capable students may select into and succeed in the most challenging fields, leading into occupational positions that involve the highest labour market returns. By contrast, less capable students may attempt to avoid failure by choosing less demanding fields of study with fewer labour market rewards.

Over the course of educational expansion, a tertiary degree may have become a less reliable productivity signal for employers (Jackson et al. 2005: 12; Van de Werfhorst 2002: 287; Hansen 2001: 210). This is because tertiary degrees offer a 'noisier' signal regarding applicants' unobservable attributes such as ability or motivation compared to former times. Amidst higher education expansion, employers may assume that the signalling costs for attaining higher education are less negatively correlated with individuals' productivity, as more and more individuals are able to acquire this signal (Spence 1973). Therefore, employers feel less certain whether a tertiary degree indicates job ap- plicants' higher ability or motivation and therefore higher productivity compared to lower educational certificates. In order to identify the highly able and motivated students among the increasing pool of higher education graduates, employers may increasingly rely on signals such as the field of study (Dörfler and Van de Werfhorst 2009; Jackson et al. 2005). This may be because fields of study increasingly differ in terms of selectivity over time.

During educational expansion increasingly more untalented students are supposed to have gained access to higher education (Walker and Zhu 2005; Gebel and Pfeiffer 2007). At school level, Becker et al. (2006) find that $7^{\text {th }}$ graders in upper secondary education (Gymnasium) show significantly lower average skills in mathematics at the beginning of the 1990s than at the end of the 1960s. In order to minimize the risk of drop out, the growing proportion of less able Abitur-holders may select into less academically challenging fields like humanities, social sciences or arts and, consequently, lower the average ability level of students in these fields. In contrast, due to the more demanding curriculum the ability levels of students in STEM fields may be less affected or remain rather unaffected during educational expansion (Reimer et al. 2008; Clark 1978). Accordingly, US students in STEM fields have been found to have higher math and verbal abilities than students from humanities, social sciences and business (Arcidiacono 2004). For Germany, Reimer and Pollak (2010) show that the better students' Abitur grades are the lower students' likelihood of studying humanities and social sciences in almost all school leaver cohorts across time. A decrease in students' average ability in less demanding fields may further involve a decline in teaching standards in curricula in those fields (Walker and Zhu 2005). This might additionally contribute to a devaluation of humanities, social sciences and arts in the labour market.

Given this scenario, the signalling value of tertiary degrees in humanities, social sciences, arts or social services in the labour market may have declined, while the signalling value of degrees in STEM fields continues to be as high as prior to higher education expansion. As a consequence, employers increasingly prefer graduates from academically demanding and more selective STEM fields over graduates from the less demanding and less selective fields of humanities, social sciences and arts in their hiring decisions over time.

\subsection{Changes in the demand for graduates from different fields of study}

From a demand-side perspective, skill-biased technological change (SBTC) predicts that the exogenous expansion of computer-based technology increased demand for highskilled analytical, non-routine cognitive tasks in the labour 
market (e.g. Autor et al. 1998; Acemoglu 2002). In addition, compositional shifts in the occupational structure may have increased or decreased the demand for particular fields of study.

In West Germany, the composition of graduate occupations has changed tremendously during occupational upgrading: high-skilled positions in social and cultural services (e.g. medical services, education, social work, services related to cultural activities in the arts, media etc.) have more slowly increased, while technical and particularly administrative and managerial positions increased with a faster rate (Klein 2011b). Hence, the share of high-skilled positions in social and cultural services has relatively decreased among the pool of graduate occupations and the share of technical, administrative and managerial positions has relatively increased. These compositional changes may imply that some fields of study have grown in demand, e. g. business and economics, science and mathematics, while other fields, e. g. humanities, social services and arts have become less demanded over time. In other words, the partial labour market for graduates from STEM fields and business has been growing, while it has been declining for graduates from humanities and social sciences.

Paglin and Rufolo (1990) assume that human capital based on mathematical ability is scarcer than human capital that is formed by verbal ability. Math and economic skills tend to have become increasingly important for all kinds of jobs (Mitra 2002). Accordingly, it was shown that math and science abilities predict salaries to a higher extent than in former times (Murnane et al. 1995). Therefore, graduates from STEM fields, economics and business may be increasingly demanded regardless of the partial labour market the vacancies are situated in. In contrast, graduates from humanities, social sciences and arts may have increasing difficulties to find employment in the high-skilled labour market due their lack of math skills.

Both from a supply and demand perspective I derive the hypothesis that graduates' field of study became increasingly relevant for early occupational attainment in the labour market over time. In particular, graduates from less academically challenging and less demanded fields of humanities, social sciences, arts or social services and education may have become more disadvantaged in terms of occupational attainment compared to graduates from the more academically challenging and more demanded STEM fields over time (Hypothesis la).

\subsection{Channelling graduates into the workplace}

According to labour market segmentation theories (e.g. Sørensen and Kalleberg 1981), the labour market is composed of a series of partial labour markets, which are not open to all job applicants alike. The German labour mar- ket is known as prototypical case of an occupational labour market where job applicants are matched to jobs according to their occupation-specific credentials (Gangl 2003b; Marsden 1990). While this characterisation mainly refers to the German apprenticeship system, it is to some degree also valid for the link between higher education and the labour market (Leuze 2007).

Given the occupationally segmented labour market in West Germany, the signalling assumption of two national queues of job applicants and job vacancies seem to be an inappropriate approach for explaining differences in occupational attainment between graduates from different fields of study. Changes in selectivity in one field of study group and the accompanied occupational segment do not have any impact on graduates' job allocation in another field of study group and occupational segment. Field of study differences in labour market returns are mainly a matter of the degree of linkage between fields of study and occupational segments and field-specific supply-demand balances. While graduates from more general fields are worse off in terms of accessing appropriate graduate occupations due to their lack of occupation-specific skills at all times, graduates with occupation-specific skills may have more difficulties in case of an oversupply of graduates from their fields due to the lack of general skills and the restriction to particular occupational segments.

STEM fields teach occupation-specific skills and graduates from these fields are prepared for specialised technical and engineering labour markets. In these partial labour markets recruitment is strongly based on job applicants who graduated from the corresponding field of study. Successful labour market integration among these graduates thus depends on the pool of job openings in the corresponding occupational segment as well as the number of competitive candidates from the same field of study (Kriesi et al. 2010).

In contrast, graduates from humanities, social sciences and arts are taught rather general skills, have a less distinct occupational profile and therefore need to compete more often with graduates of occupation-specific fields and lower educated individuals about any available job vacancies in the high-skilled labour market (Klein 2011a). Accordingly, graduates from the professions and STEM fields are, in general, less likely to be in a mismatched occupation than other fields (Grotheer et al. 2012).

Returns to higher education are shaped by the relative evolution of higher education expansion and occupational upgrading in the labour market over time (Gangl 2003a). By international comparison higher education expansion has taken place on a rather moderate level in West Germany (OECD 2013; Müller and Wolbers, 2003). Likewise, the occupational upgrading of high-skilled occupational positions has more or less kept pace with higher education expansion (Oesch and Rodríguez Menés 2011; Klein 2011b). 
Hence, the increasing number of graduates was able to find employment in appropriate graduate jobs and incidences of overeducation have not been dramatically increasing over time.

Although there might be short-term imbalances between supply and demand of graduates in some occupational segments, it is rather unlikely that there is a continuous trend towards increasing field of study differences in occupational attainment in West Germany over time. Given the occupationally segmented structure of the labour market, the modest educational expansion and sufficient occupational upgrading, hypothesis $1 b$ argues that field of study differences in occupational attainment did not increasingly diverge over time.

\section{Data, variables and methods}

\subsection{Data and sample}

For the analyses, I use a long series of German labour force surveys, the Microcensus, covering one per cent of the German households. The time series comprises the Microcensus Scientific-Use-Files (70 per cent random subsamples) 1980, 1985, 1987, 1989, 1991, 1993, 1995, 1996, 2000 and 2004-2008 and concentrates on the West German population. The sample is restricted to tertiary graduates differentiating between first-tier university and second-tier polytechnics (Fachhochschule) graduates.

The analysis focuses on labour market entrants because changes in the supply- and demand-side are more immediate with labour market entry cohorts (Gangl 2003a). Since the Microcensus lacks information on the first job, I approximated tertiary graduates' labour market entrance with the age group 30-34. In order to grasp the magnitude of higher education expansion and increasing graduate competition, the age group is slightly older than the typical graduation age. This is because a considerable proportion of German higher education students graduate well into their thirties (Müller and Wolbers 2003) and students increasingly graduate in later ages across birth cohorts (Hillmert and Jacob 2004). ${ }^{1}$ Due to gender segregation in the German labour market, all analyses are conducted separately for men and women. The graduate sample across all Microcensus years is $N=30,889$ for men and $N=22,244$ for women.

\footnotetext{
${ }^{1}$ Selecting tertiary graduates aged 25 to 34 would heavily underestimate the strength of educational expansion, as increasingly larger shares of younger students remain in tertiary education and thus exclude from the sample.
}

\subsection{Variables}

I use two indicators of occupational allocation as dependent variables: access to the service class and risk of unemployment. Both indicators have to be taken into account in order to fully capture changes in the relationship between graduates' field of study and labour market positions. During higher education expansion and structural shifts in the labour market graduates from humanities, arts and social sciences might not only be disadvantaged in attaining beneficial career positions but may have problems to find employment at all. Due the strong prevalence of occupationally segmented labour markets and the dual system of apprenticeship, graduates from fields providing rather general skills may have difficulties to compete with vocationally-qualified school-leavers around intermediate and lower occupational positions and may therefore become rather unemployed.

With slight modifications, the status of unemployment at the time of the interview is defined according to ILO convention: not working for a single hour during the reference week and actively seeking for a job in the last four weeks (ILO 2005). However, individuals that participate in school-based education are not considered as belonging to the labour force irrespective of their labour force status.

Service class positions are operationalized with the EGPclass schema (Erikson and Goldthorpe 1992) as EGP I and II using information on detailed occupation codes (German Klassifizierung der Berufe (KldB)) and employment status. EGP I includes higher-grade professionals, administrators, and officials, managers in large industrial establishments and large proprietors. EGP II contains lower-grade professionals, administrators, and officials, higher-grade technicians, managers in small industrial establishments and supervisors of non-manual employees.

The EGP class schema adheres closely a Weberian class concept, i.e. social classes are strictly formed by labour market relations and thus determine individuals' life chances by stratifying access to material resources. Service class positions (EGP I and II) are an appropriate indicator for graduates' occupational attainment since it involves a service relationship that offers the chance of steadily rising salaries throughout working life and long-term career success in exchange for employees' commitment to the organization and high job performance. These positions not only include a salary and various perquisites but also prospective elements such as promotion opportunities and security both in employment and after retirement. Service class positions offer 'well-defined career opportunities' (Erikson and Goldthorpe 1992: 42) and life course benefits, which can therefore be unequivocally regarded as hierarchically above all other classes (Erikson and Goldthorpe 1992: 46). The EGP-class schema involves high criterion validity 
Tab. 1 Higher education expansion and the distribution of fields of study (Percentages). (German Microcensus, Scientific-Use-Files 1980-2008)

\begin{tabular}{|c|c|c|c|c|c|c|c|c|}
\hline Men & 1980 & $1985-87$ & 1989-93 & 1995-96 & 2000 & 2004-05 & $2006-08$ & $N$ \\
\hline Overall $^{\mathrm{a}}$ & 14 & 16 & 19 & 26 & 29 & 27 & 27 & \\
\hline Teaching & 12 & 7 & 5 & 2 & 4 & 6 & 6 & 1681 \\
\hline Med./Pharm & 9 & 8 & 9 & 8 & 6 & 5 & 5 & 2205 \\
\hline Law & 7 & 6 & 5 & 5 & 5 & 6 & 5 & 1680 \\
\hline Science/Math & 14 & 15 & 16 & 19 & 14 & 12 & 13 & 4640 \\
\hline Engineer./Agron & 27 & 29 & 32 & 33 & 38 & 33 & 28 & 9589 \\
\hline Bus./Manag & 16 & 18 & 21 & 23 & 22 & 27 & 28 & 7016 \\
\hline Hum./Soc./Arts & 8 & 10 & 8 & 8 & 8 & 8 & 9 & 2656 \\
\hline Soc. Serv./Educ & 8 & 7 & 5 & 3 & 3 & 4 & 4 & 1422 \\
\hline$N$ & 1725 & 4794 & 6753 & 5166 & 2468 & 4042 & 5941 & 30,889 \\
\hline Women & 1980 & $1985-87$ & 1989-93 & 1995-96 & 2000 & 2004-05 & 2006-08 & $N$ \\
\hline Overall $^{\mathrm{a}}$ & 7 & 10 & 13 & 18 & 21 & 23 & 25 & \\
\hline Teaching & 30 & 20 & 18 & 10 & 14 & 19 & 19 & 3905 \\
\hline Med./Pharm & 10 & 8 & 10 & 11 & 10 & 7 & 8 & 1945 \\
\hline Law & 2 & 4 & 5 & 5 & 5 & 6 & 7 & 1179 \\
\hline Science/Math & 4 & 8 & 9 & 10 & 9 & 6 & 5 & 1646 \\
\hline Engineer./Agron & 4 & 5 & 8 & 9 & 10 & 10 & 9 & 1858 \\
\hline Bus./Manag & 6 & 10 & 14 & 18 & 19 & 24 & 23 & 3971 \\
\hline Hum./Soc./Arts & 16 & 19 & 19 & 21 & 21 & 17 & 17 & 4158 \\
\hline Soc. Serv./Educ & 27 & 26 & 19 & 15 & 12 & 12 & 11 & 3582 \\
\hline$N$ & 816 & 2850 & 4420 & 3473 & 1629 & 3408 & 5648 & 22,244 \\
\hline
\end{tabular}

aPercentage of HE graduates (age 30-34) among all labour market entrants (Lower secondary education and below: age 20-24; upper secondary education: age 25-29)

capturing cleavages in job characteristics and benefits that it is supposed to capture (Goldthorpe and McKnight 2006).

To assess changes in the association between graduates' fields of study and occupational segments, the service class is further differentiated into three segments: (1) administrative and managerial positions such as managers, accountants or governmental and non-governmental administrators, (2) technical experts such as engineers or scientists and social and cultural services (3) such as medical services, education, social work, services related to cultural activities in the arts, media etc. (for a detailed classification see Tab. 7 in the appendix).

Respondents' field of study is measured with eight groups: teaching, law, medicine/pharmacy, humanities/ social sciences/arts, social services/education, science/ mathematics and engineering/agronomics and business and management (for a detailed classification see Tab. 8 in the appendix).

Nationality and tertiary institution are included as confounders in all models. Nationality is a binary indicator differentiating between German and non-German citizenship. Tertiary institution differentiates between universities and polytechnics (Fachhochschule).

\subsection{Analytic strategy}

Based on the pooled Microcensus sample, I conducted linear probability models (LPMs) for both outcomes of risk of unemployment and access to the service class. In order to model changes over time these models included interaction terms between field of study and seven periods: 1980, 1985-1987, 1989-1993, 1995/1996, 2000, 2004-2005 and 2006-2008. Comparing coefficients from non-linear probability models across samples is problematic since it is unclear whether differences in the effect of the predictor variable can be attributed to real differences or to differences in residual variation across models (Mood 2010). For the same reasons, I compare average marginal effects (AMEs) across survey years when differentiating the service class into four segments EGP I/II administrative and managerial, EGP I/II technical expert, EGP I/II social and cultural services and EGP III-VII) in separate multinomial logistic regressions. 
Tab. 2 Occupational upgrading and compositional changes (Percentages). (German Microcensus, Scientific-Use-Files 1980-2008)

\begin{tabular}{|c|c|c|c|c|c|c|c|c|}
\hline Men & 1980 & $1985-87$ & 1989-93 & $1995-96$ & 2000 & 2004-05 & $2006-08$ & $N$ \\
\hline $\begin{array}{l}\text { EGP I/II admin./ } \\
\text { manag }\end{array}$ & 6 & 7 & 9 & 13 & 17 & 17 & 17 & 13,969 \\
\hline $\begin{array}{l}\text { EGP I/II technical } \\
\text { experts }\end{array}$ & 6 & 7 & 8 & 11 & 12 & 11 & 11 & 10,849 \\
\hline $\begin{array}{l}\text { EGP I/II social ser- } \\
\text { vices }\end{array}$ & 7 & 7 & 6 & 8 & 7 & 8 & 8 & 8843 \\
\hline EGP III-VII & 80 & 79 & 77 & 69 & 64 & 64 & 64 & 89,059 \\
\hline$N$ & 11,076 & 25,299 & 30,909 & 16,965 & 7518 & 12,360 & 18,593 & 122,720 \\
\hline Women & 1980 & $1985-87$ & 1989-93 & $1995-96$ & 2000 & 2004-05 & $2006-08$ & $N$ \\
\hline $\begin{array}{l}\text { EGP I/II admin./ } \\
\text { manag }\end{array}$ & 5 & 6 & 7 & 12 & 13 & 14 & 14 & 10,163 \\
\hline $\begin{array}{l}\text { EGP I/II technical } \\
\text { experts }\end{array}$ & 2 & 2 & 3 & 4 & 4 & 4 & 4 & 3260 \\
\hline $\begin{array}{l}\text { EGP I/II social ser- } \\
\text { vices }\end{array}$ & 14 & 15 & 15 & 17 & 18 & 21 & 22 & 18,189 \\
\hline EGP III-VII & 80 & 77 & 75 & 68 & 65 & 62 & 60 & 75,823 \\
\hline$N$ & 8928 & 21,576 & 27,332 & 14,662 & 6154 & 11,343 & 17,440 & 107,435 \\
\hline
\end{tabular}

Sample of labour market entrants: lower secondary education and below: age 20-24; upper secondary education: age 25-29; HE graduates: age $30-34$

\section{Results}

\subsection{Changes in the recruitment pool of graduates}

Tab. 1 shows the supply-side changes in terms of higher education expansion among all labour market entrants and the distribution of fields of study among graduates. The proportion of higher education graduates increased for both men and particularly women between 1980 and the end of the 2000s. However, in the last decade the expansion came to a standstill for men and only slightly increased for women.

The distribution of fields of study across sexes shows the well-known gender segregation in higher education. For men, engineering and science/mathematics as well as business/management are the most popular fields. Women opt more often for teaching, humanities/social sciences/arts and social services/education. The most salient change over time was the increase in the percentage of students in business and management studies for both sexes. In contrast, the percentage of individuals with teaching, medicine or social services/education degrees decreased over time.

\subsection{Occupational upgrading and compositional changes}

Tab. 2 shows demand-side changes in the labour market in terms of occupational upgrading and compositional changes in the occupational structure among labour market entrants over time. For both sexes, the share of occupational positions below the service class (EGP III-VII) substantially decreased particularly in the 1990s (from $80 \%$ to $64 \%$ and $60 \%$ respectively). Hence, not only the supply of gradu- ates increased but also the demand for high-skilled labour. When differentiating between segments of the service class, this increase in high-skilled positions took predominantly place in the administrative and managerial segment, more so for men than for women. While the share of individuals working in technical expert positions increased for men as well, an increase of social and cultural services positions contributed to the expansion of the service class for women.

Tab. 3 illustrates graduates' changing employment and occupational destinations over time. The 1980s have been the most problematic decade for higher education graduates in West Germany: both unemployment rate and proportion of graduates working in lower and intermediate occupational positions (EGP III-VII) increased for both sexes. Accordingly, this decade was characterised by an occupational upgrading that somewhat lagged behind HE expansion producing an oversupply of graduates (Klein 2011b). From the mid-1990s onwards the situation in the graduate labour market improved again and graduates' unemployment rate and percentage working below the service class decreased.

In line with compositional changes in the service class, the share of graduates working in the administrative and managerial service class segment substantially increased while the share of employees in the social and cultural services segment decreased. This may imply that graduates from business/management and STEM fields benefited more from occupational upgrading in terms of an increasing demand than graduates from humanities/social sciences/ arts. 
Tab. 3 Graduates' employment and occupational destinations over time (Percentages). (German Microcensus, Scientific-Use-Files 1980-2008)

\begin{tabular}{|c|c|c|c|c|c|c|c|c|}
\hline Men & 1980 & $1985-87$ & 1989-93 & 1995-96 & 2000 & 2004-05 & $2006-08$ & $N$ \\
\hline Unemployment rate & 1 & 4 & 4 & 4 & 2 & 3 & 2 & \\
\hline$N$ & 1714 & 4748 & 6678 & 5115 & 2448 & 4005 & 5895 & 30603 \\
\hline EGP I/II & 86 & 82 & 80 & 80 & 83 & 84 & 85 & \\
\hline \multicolumn{9}{|l|}{ EGP I/II segments } \\
\hline Admin./manag & 17 & 22 & 25 & 26 & 32 & 33 & 34 & \\
\hline Technical experts & 30 & 30 & 32 & 34 & 33 & 32 & 29 & \\
\hline Social services & 39 & 31 & 23 & 20 & 18 & 19 & 21 & \\
\hline EGP III-VII & 15 & 18 & 19 & 20 & 17 & 16 & 16 & \\
\hline$N$ & 1691 & 4544 & 6401 & 4876 & 2386 & 3845 & 5707 & 29,450 \\
\hline Women & 1980 & $1985-87$ & 1989-93 & 1995-96 & 2000 & 2004-05 & $2006-08$ & $N$ \\
\hline Unemployment rate & 3 & 8 & 8 & 6 & 4 & 5 & 4 & \\
\hline$N$ & 642 & 2326 & 3578 & 2912 & 1441 & 2926 & 4937 & 18,762 \\
\hline EGP I/II & 88 & 84 & 77 & 78 & 80 & 82 & 82 & \\
\hline \multicolumn{9}{|l|}{ EGP I/II segments } \\
\hline Admin./manag & 5 & 11 & 15 & 20 & 21 & 25 & 26 & \\
\hline Technical experts & 3 & 6 & 10 & 11 & 13 & 12 & 11 & \\
\hline Social services & 79 & 67 & 52 & 47 & 45 & 45 & 46 & \\
\hline EGP III-VII & 12 & 16 & 23 & 22 & 20 & 18 & 18 & \\
\hline$N$ & 624 & 2135 & 3279 & 2716 & 1387 & 2772 & 4728 & 17,641 \\
\hline
\end{tabular}

Sample restricted to HE graduates: age 30-34

\subsection{Graduates' field of study and occupational destinations over time}

Tab. 4 shows the relationship between graduates' field of study and unemployment risk over time for both sexes separately. The column '1980' shows the main effects of the field of study compared to the reference category science and mathematics in the pooled linear probability model. The following columns indicate changes in the effect of field of study on the probability of unemployment across different periods (interaction terms between field of study and period).

Graduates from different fields of study do not significantly differ in their probability of being unemployed compared to graduates from science and mathematics in 1980 . There are also no consistent developments in the association between field of study and unemployment over time. Changes are rather volatile and unsystematic. Even though there was a more problematic period in terms of overall graduate unemployment in the 1980s until mid-1990s, graduates from different fields of study seem to have been similarly affected by joblessness. There is clearly no continuously increasing unemployment gap between different fields of study across periods.

Tab. 5 shows the results for the association between field of study and access to managerial and professional occupations over time. As for unemployment risks, there are no substantial differences between fields of study in occupational attainment. The only exception are graduates from business and management. Both female and male graduates from these studies have a significantly lower probability of gaining access to the service class than graduates from all other fields. Since business and management studies are more practically oriented, they may have stronger links to routine non-manual employment in administration and commerce rather than to traditional graduate occupations. Over time, graduates from business and management were able to reduce their disadvantages in terms of accessing the service class to all other groups. For male graduates from business, this change has been significant at the $1 \%$-level compared to graduates from science/mathematics from the mid-1990s onwards. This may indicate that business and management graduates are increasingly demanded in the course of compositional occupational changes in the highskilled labour market. Still, they remain strongly disadvantaged compared to other fields in terms of occupational attainment.

For men, there is no consistent trend in the gap between humanities/social sciences/arts and social services/ education and STEM fields in access to the service class across periods. Female graduates from humanities/social sciences/arts and social services/education became somewhat more disadvantaged in accessing managerial and professional occupations compared to female graduates in 
Tab. 4 Graduates' field of study and unemployment risk over time (linear probability model). (German Microcensus, Scientific-Use-Files 1980-2008)

\begin{tabular}{|c|c|c|c|c|c|c|c|}
\hline $\operatorname{Men}(N=30,603)$ & 1980 & $1985-1987$ & $1989-1993$ & $1995 / 1996$ & 2000 & $2004-2005$ & $2006-2008$ \\
\hline \multicolumn{8}{|l|}{ Ref. Science/Mathematics } \\
\hline \multirow[t]{2}{*}{ Medicine/Pharmacy } & -0.00 & -0.01 & $-0.03^{*}$ & -0.01 & -0.00 & 0.01 & 0.00 \\
\hline & $(0.01)$ & $(0.01)$ & $(0.01)$ & $(0.02)$ & $(0.02)$ & $(0.02)$ & $(0.01)$ \\
\hline \multirow[t]{2}{*}{ Teaching } & 0.01 & 0.01 & 0.00 & 0.00 & -0.00 & -0.01 & -0.01 \\
\hline & $(0.01)$ & $(0.02)$ & $(0.02)$ & $(0.03)$ & $(0.02)$ & $(0.02)$ & $(0.02)$ \\
\hline \multirow[t]{2}{*}{ Law } & 0.01 & 0.01 & -0.03 & -0.01 & 0.02 & 0.01 & -0.00 \\
\hline & $(0.01)$ & $(0.02)$ & $(0.02)$ & $(0.02)$ & $(0.02)$ & $(0.02)$ & $(0.02)$ \\
\hline \multirow[t]{2}{*}{ Engineering/Agronomics } & -0.00 & 0.00 & -0.02 & -0.01 & -0.00 & 0.02 & 0.00 \\
\hline & $(0.01)$ & $(0.01)$ & $(0.01)$ & $(0.01)$ & $(0.01)$ & $(0.01)$ & $(0.01)$ \\
\hline \multirow[t]{2}{*}{ Business/Management } & 0.01 & -0.02 & $-0.04^{* *}$ & -0.01 & -0.02 & -0.01 & -0.01 \\
\hline & $(0.01)$ & $(0.01)$ & $(0.01)$ & $(0.01)$ & $(0.01)$ & $(0.01)$ & $(0.01)$ \\
\hline \multirow[t]{2}{*}{ Humanities/Social sciences/Arts } & 0.00 & $0.05^{*}$ & 0.01 & 0.00 & -0.00 & 0.03 & 0.02 \\
\hline & $(0.01)$ & $(0.02)$ & $(0.02)$ & $(0.02)$ & $(0.02)$ & $(0.02)$ & $(0.02)$ \\
\hline \multirow[t]{2}{*}{ Social services/Education } & 0.03 & 0.03 & 0.00 & $-0.05^{*}$ & 0.00 & 0.01 & -0.02 \\
\hline & $(0.02)$ & $(0.03)$ & $(0.03)$ & $(0.02)$ & $(0.03)$ & $(0.03)$ & $(0.02)$ \\
\hline Women $(N=18,762)$ & 1980 & $1985-1987$ & $1989-1991$ & 1995/1996 & 2000 & $2004-2005$ & $2006-2008$ \\
\hline \multicolumn{8}{|l|}{ Ref. Science/Mathematics } \\
\hline \multirow[t]{2}{*}{ Medicine/Pharmacy } & -0.01 & -0.02 & -0.00 & -0.05 & 0.06 & 0.00 & 0.00 \\
\hline & $(0.04)$ & $(0.05)$ & $(0.05)$ & $(0.05)$ & $(0.05)$ & $(0.05)$ & $(0.05)$ \\
\hline \multirow[t]{2}{*}{ Teaching } & 0.00 & -0.05 & 0.01 & -0.06 & -0.01 & -0.04 & -0.02 \\
\hline & $(0.04)$ & $(0.05)$ & $(0.04)$ & $(0.04)$ & $(0.04)$ & $(0.04)$ & $(0.04)$ \\
\hline \multirow[t]{2}{*}{ Law } & 0.04 & -0.08 & -0.06 & -0.06 & -0.01 & -0.02 & -0.04 \\
\hline & $(0.08)$ & $(0.09)$ & $(0.08)$ & $(0.08)$ & $(0.08)$ & $(0.08)$ & $(0.08)$ \\
\hline \multirow[t]{2}{*}{ Engineering/Agronomics } & -0.05 & -0.00 & 0.05 & 0.01 & 0.07 & 0.05 & 0.06 \\
\hline & $(0.04)$ & $(0.05)$ & $(0.04)$ & $(0.04)$ & $(0.04)$ & $(0.04)$ & $(0.04)$ \\
\hline \multirow[t]{2}{*}{ Business/Management } & -0.01 & -0.04 & -0.01 & -0.07 & 0.01 & -0.02 & -0.00 \\
\hline & $(0.05)$ & $(0.06)$ & $(0.05)$ & $(0.05)$ & $(0.05)$ & $(0.05)$ & $(0.05)$ \\
\hline \multirow[t]{2}{*}{ Humanities/Social sciences/Arts } & -0.01 & -0.05 & 0.02 & -0.02 & 0.02 & 0.03 & 0.03 \\
\hline & $(0.04)$ & $(0.05)$ & $(0.05)$ & $(0.05)$ & $(0.04)$ & $(0.05)$ & $(0.04)$ \\
\hline \multirow[t]{2}{*}{ Social services/Education } & -0.03 & 0.04 & 0.03 & 0.01 & 0.05 & 0.03 & 0.04 \\
\hline & $(0.04)$ & $(0.05)$ & $(0.04)$ & $(0.04)$ & $(0.04)$ & $(0.04)$ & $(0.04)$ \\
\hline
\end{tabular}

LPM includes main effects of nationality, HE institution and interaction terms with period; robust standard errors in parentheses; ${ }^{*} p<0.05$, ${ }^{* *} p<0.01,{ }^{* * *} p<0.001$

STEM fields over time. However, these changes are not consistently significant at conventional criteria. ${ }^{2}$

Tab. 6 shows field of study differences in terms of average marginal effects in access to different service class segments. Since graduates from professional programs almost exclusively end up in particular segments (medicine/ pharmacy and teaching in social and cultural services, law in administrative/management) when being employed in the service class, estimates for the professions are not shown in this table.

As with the vocational training market, West Germany's occupational linkages with fields of study are evident in the graduate labour market, too. Students from different fields

2 The results do not change when including employment sector as additional covariate into the models (results upon request). of study enter distinct occupational segments after graduation. While graduates from humanities/social sciences/arts and social services/education have strong advantages in attaining positions in the social and cultural services compared to other fields, graduates from STEM fields have a higher probability of being employed in the technical expert segment. When gaining access to the service class business and management graduates are more likely to find employment in administrative and managerial occupations than all other groups. These patterns are clearly less pronounced among women than among men at the beginning of the observation period.

Over time, some shifts in these patterns can be identified. For men, all field groups became increasingly disadvantaged (engineering/agronomics, humanities/social sciences/arts, social services/education) or less advantaged 
Tab. 5 Graduates' field of study and access to service class positions, EGP I and II (linear probability model). (German Microcensus, ScientificUse-Files 1980-2008)

\begin{tabular}{|c|c|c|c|c|c|c|c|}
\hline $\operatorname{Men}(N=29,450)$ & 1980 & $1985-1987$ & 1989-1993 & $1995 / 1996$ & 2000 & 2004-2005 & $2006-2008$ \\
\hline \multicolumn{8}{|l|}{ Ref. Science/Mathematics } \\
\hline \multirow[t]{2}{*}{ Medicine/Pharmacy } & $0.05^{*}$ & $-0.07^{*}$ & -0.06 & -0.05 & -0.04 & -0.05 & -0.03 \\
\hline & $(0.02)$ & $(0.03)$ & $(0.03)$ & $(0.04)$ & $(0.04)$ & $(0.03)$ & $(0.03)$ \\
\hline \multirow[t]{2}{*}{ Teaching } & 0.05 & 0.00 & 0.03 & 0.03 & 0.02 & 0.02 & 0.02 \\
\hline & $(0.03)$ & $(0.03)$ & $(0.03)$ & $(0.03)$ & $(0.03)$ & $(0.03)$ & $(0.03)$ \\
\hline \multirow[t]{2}{*}{ Law } & -0.03 & 0.01 & 0.03 & 0.06 & -0.03 & 0.02 & 0.02 \\
\hline & $(0.03)$ & $(0.04)$ & $(0.04)$ & $(0.04)$ & $(0.05)$ & $(0.04)$ & $(0.04)$ \\
\hline \multirow[t]{2}{*}{ Engineering/Agronomics } & -0.01 & -0.02 & 0.03 & -0.02 & -0.04 & -0.03 & 0.01 \\
\hline & $(0.03)$ & $(0.03)$ & $(0.03)$ & $(0.03)$ & $(0.03)$ & $(0.03)$ & $(0.03)$ \\
\hline \multirow[t]{2}{*}{ Business/Management } & $-0.29^{* * *}$ & 0.07 & 0.07 & $0.12^{* *}$ & $0.13^{* *}$ & $0.14^{* * * *}$ & $0.14^{* * *}$ \\
\hline & $(0.04)$ & $(0.04)$ & $(0.04)$ & $(0.04)$ & $(0.04)$ & $(0.04)$ & $(0.04)$ \\
\hline \multirow[t]{2}{*}{ Humanities/Social sciences/Arts } & -0.06 & 0.01 & 0.04 & 0.08 & -0.07 & -0.02 & -0.02 \\
\hline & $(0.04)$ & $(0.04)$ & $(0.04)$ & $(0.04)$ & $(0.05)$ & $(0.04)$ & $(0.04)$ \\
\hline \multirow[t]{2}{*}{ Social services/Education } & -0.03 & 0.00 & -0.01 & 0.04 & $-0.15^{*}$ & -0.02 & -0.02 \\
\hline & $(0.04)$ & $(0.04)$ & $(0.04)$ & $(0.04)$ & $(0.07)$ & $(0.05)$ & $(0.04)$ \\
\hline Women $(N=17,641)$ & 1980 & $1985-1987$ & 1989-1991 & 1995/1996 & 2000 & $2004-2005$ & $2006-2008$ \\
\hline \multicolumn{8}{|l|}{ Ref. Science/Mathematics } \\
\hline \multirow[t]{2}{*}{ Medicine/Pharmacy } & 0.09 & -0.07 & -0.02 & 0.01 & 0.01 & -0.07 & -0.02 \\
\hline & $(0.07)$ & $(0.08)$ & $(0.08)$ & $(0.08)$ & $(0.08)$ & $(0.08)$ & $(0.08)$ \\
\hline \multirow[t]{2}{*}{ Teaching } & 0.11 & -0.03 & 0.03 & 0.08 & 0.03 & -0.04 & -0.01 \\
\hline & $(0.08)$ & $(0.08)$ & $(0.08)$ & $(0.08)$ & $(0.08)$ & $(0.08)$ & $(0.08)$ \\
\hline \multirow[t]{2}{*}{ Law } & 0.06 & -0.10 & -0.04 & 0.03 & 0.03 & -0.13 & -0.04 \\
\hline & $(0.10)$ & $(0.11)$ & $(0.11)$ & $(0.11)$ & $(0.11)$ & $(0.11)$ & $(0.11)$ \\
\hline \multirow[t]{2}{*}{ Engineering/Agronomics } & -0.17 & 0.05 & 0.15 & 0.12 & 0.16 & 0.12 & 0.19 \\
\hline & $(0.14)$ & $(0.15)$ & $(0.15)$ & $(0.15)$ & $(0.15)$ & $(0.14)$ & $(0.14)$ \\
\hline \multirow[t]{2}{*}{ Business/Management } & $-0.34^{* *}$ & 0.05 & 0.11 & $0.28^{*}$ & 0.14 & 0.16 & 0.14 \\
\hline & $(0.11)$ & $(0.12)$ & $(0.11)$ & $(0.11)$ & $(0.12)$ & $(0.11)$ & $(0.11)$ \\
\hline \multirow[t]{2}{*}{ Humanities/Social sciences/Arts } & 0.04 & -0.07 & -0.08 & 0.02 & -0.10 & $-0.17^{*}$ & -0.11 \\
\hline & $(0.08)$ & $(0.08)$ & $(0.08)$ & $(0.08)$ & $(0.09)$ & $(0.08)$ & $(0.08)$ \\
\hline \multirow[t]{2}{*}{ Social services/Education } & 0.08 & -0.06 & -0.11 & -0.05 & -0.09 & -0.15 & -0.14 \\
\hline & $(0.07)$ & $(0.08)$ & $(0.08)$ & $(0.08)$ & $(0.09)$ & $(0.08)$ & $(0.08)$ \\
\hline
\end{tabular}

LPM includes main effects of nationality, HE institution and interaction terms with period; robust standard errors in parentheses; ${ }^{*} p<0.05$, ${ }^{* *} p<0.01,{ }^{* * *} p<0.001$

(business/management) in access to the administrative and managerial segments compared to science and mathematics. Hence, for men, the segment of administrative and managerial positions has been increasingly dominated by science/mathematics and business/management graduates over time. In contrast, in access to technical expert positions, some fields (business/management, humanities/social sciences/arts and social services/education) reduced the gap towards science and mathematics or had a larger probability advantage (engineering) across periods. Hence, male graduates from science and mathematics were increasingly found in administrative and managerial positions rather than technical expert positions. The segment of social and cultural services continued to be dominated by graduates from humanities/social sciences/arts and social services/ education.
For women, business and management graduates became somewhat more advantaged in attaining administrative and managerial positions over other field groups across time. While for technical expert positions the gap between humanities/social sciences/arts, social services/education and STEM fields increased, it was the opposite for positions in social and cultural services. Hence, patterns became increasingly similar to those of men across periods.

\section{Discussion}

The literature commonly argues that the field of study became a more important selection criterion for employers during educational expansion (Jackson et al. 2005; Hansen 2001; Van de Werfhorst 2002). When higher education is 
Tab. 6 Field of study and access to service class segments (average marginal effects). (German Microcensus, Scientific-Use-Files 1980-2008)

\begin{tabular}{|c|c|c|c|c|c|c|c|}
\hline \multicolumn{8}{|l|}{$\operatorname{Men}(N=29,450)$} \\
\hline EGP I/II admin./manag & 1980 & $1985-1987$ & 1989-1993 & $1995 / 1996$ & 2000 & 2004-2005 & $2006-2008$ \\
\hline \multicolumn{8}{|l|}{ Ref. Science/Mathematics } \\
\hline \multirow[t]{2}{*}{ Engineering/Agronomics } & -0.02 & $-0.15^{* * *}$ & $-0.15^{* * *}$ & $-0.18^{* * *}$ & $-0.37^{* * *}$ & $-0.38^{* * *}$ & $-0.36^{* * *}$ \\
\hline & $(0.03)$ & $(0.02)$ & $(0.02)$ & $(0.02)$ & $(0.03)$ & $(0.03)$ & $(0.02)$ \\
\hline \multirow[t]{2}{*}{ Business/Management } & $0.21^{* * *}$ & $0.23^{* * *}$ & $0.18^{* * *}$ & $0.14^{* * *}$ & -0.01 & -0.01 & 0.03 \\
\hline & $(0.04)$ & $(0.03)$ & $(0.02)$ & $(0.02)$ & $(0.03)$ & $(0.03)$ & $(0.02)$ \\
\hline \multirow[t]{2}{*}{ Humanities/Social sciences/Arts } & $-0.07^{*}$ & $-0.13^{* * *}$ & $-0.16^{* * *}$ & $-0.23^{* * *}$ & $-0.39^{* * *}$ & $-0.37^{* * * *}$ & $-0.36^{* * *}$ \\
\hline & $(0.03)$ & $(0.03)$ & $(0.02)$ & $(0.02)$ & $(0.04)$ & $(0.03)$ & $(0.03)$ \\
\hline \multirow[t]{2}{*}{ Social services/Education } & $-0.10^{* * *}$ & $-0.20^{* * *}$ & $-0.19^{* * *}$ & $-0.27^{* * *}$ & $-0.50^{* * *}$ & $-0.41^{* * *}$ & $-0.39^{* * *}$ \\
\hline & $(0.03)$ & $(0.02)$ & $(0.02)$ & $(0.02)$ & $(0.04)$ & $(0.04)$ & $(0.03)$ \\
\hline EGP I/II technical experts & 1980 & $1985-1987$ & 1989-1991 & 1995/1996 & 2000 & 2004-2005 & $2006-2008$ \\
\hline \multicolumn{8}{|l|}{ Ref. Science/Mathematics } \\
\hline \multirow[t]{2}{*}{ Engineering/Agronomics } & 0.07 & $0.26^{* * *}$ & $0.21^{* * *}$ & $0.17^{* * *}$ & $0.35^{* * *}$ & $0.37^{* * *}$ & $0.41^{* * *}$ \\
\hline & $(0.04)$ & $(0.02)$ & $(0.02)$ & $(0.02)$ & $(0.03)$ & $(0.03)$ & $(0.02)$ \\
\hline \multirow[t]{2}{*}{ Business/Management } & $-0.36^{* * *}$ & $-0.31^{* * *}$ & $-0.35^{* * *}$ & $-0.29^{* * *}$ & $-0.14^{* * *}$ & $-0.12^{* * *}$ & $-0.12^{* * *}$ \\
\hline & $(0.04)$ & $(0.03)$ & $(0.02)$ & $(0.02)$ & $(0.03)$ & $(0.03)$ & $(0.02)$ \\
\hline \multirow[t]{2}{*}{ Humanities/Social sciences/Arts } & $-0.45^{* * *}$ & $-0.35^{* * *}$ & $-0.41^{* * *}$ & $-0.41^{* * *}$ & $-0.20^{* * *}$ & $-0.20^{* * *}$ & $-0.19^{* * *}$ \\
\hline & $(0.05)$ & $(0.02)$ & $(0.02)$ & $(0.02)$ & $(0.03)$ & $(0.03)$ & $(0.02)$ \\
\hline \multirow[t]{2}{*}{ Social services/Education } & $-0.54^{* * *}$ & $-0.44^{* * *}$ & $-0.46^{* * *}$ & $-0.44^{* * *}$ & $-0.26^{* * *}$ & $-0.26^{* * *}$ & $-0.24^{* * *}$ \\
\hline & $(0.04)$ & $(0.02)$ & $(0.02)$ & $(0.02)$ & $(0.03)$ & $(0.03)$ & $(0.02)$ \\
\hline EGP I/II social services & 1980 & $1985-1987$ & $1989-1991$ & 1995/1996 & 2000 & 2004-2005 & $2006-2008$ \\
\hline \multicolumn{8}{|l|}{ Ref. Science/Mathematics } \\
\hline \multirow[t]{2}{*}{ Engineering/Agronomics } & $-0.07^{*}$ & $-0.14^{* * *}$ & $-0.14^{* * *}$ & $-0.05^{* * *}$ & -0.02 & $-0.04^{* *}$ & $-0.05^{* *}$ \\
\hline & $(0.03)$ & $(0.02)$ & $(0.02)$ & $(0.01)$ & $(0.01)$ & $(0.01)$ & $(0.01)$ \\
\hline \multirow[t]{2}{*}{ Business/Management } & $-0.14^{* * *}$ & $-0.14^{* * *}$ & $-0.14^{* * *}$ & $-0.04^{* * *}$ & $-0.03^{* *}$ & -0.02 & $-0.04^{* *}$ \\
\hline & $(0.03)$ & $(0.02)$ & $(0.02)$ & $(0.01)$ & $(0.01)$ & $(0.02)$ & $(0.02)$ \\
\hline \multirow[t]{2}{*}{ Humanities/Social sciences/Arts } & $0.42^{* * *}$ & $0.41^{* * *}$ & $0.41^{* * *}$ & $0.54^{* * *}$ & $0.64^{* * *}$ & $0.45^{* * *}$ & $0.48^{* * *}$ \\
\hline & $(0.05)$ & $(0.03)$ & $(0.03)$ & $(0.02)$ & $(0.03)$ & $(0.04)$ & $(0.03)$ \\
\hline \multirow[t]{2}{*}{ Social services/Education } & $0.59^{* * *}$ & $0.60^{* * *}$ & $0.60^{* * *}$ & $0.61^{* * *}$ & $0.72^{* * * *}$ & $0.59^{* * *}$ & $0.62^{* * *}$ \\
\hline & $(0.05)$ & $(0.03)$ & $(0.03)$ & $(0.03)$ & $(0.03)$ & $(0.06)$ & $(0.04)$ \\
\hline \multicolumn{8}{|l|}{ Women $(N=17,641)$} \\
\hline EGP I/II admin./manag & 1980 & $1985-1987$ & 1989-1993 & $1995 / 1996$ & 2000 & 2004-2005 & $2006-2008$ \\
\hline \multicolumn{8}{|l|}{ Ref. Science/Mathematics } \\
\hline \multirow[t]{2}{*}{ Engineering/Agronomics } & -0.08 & -0.08 & $-0.07^{*}$ & $-0.07^{*}$ & $-0.14^{* *}$ & $-0.14^{* *}$ & $-0.09^{*}$ \\
\hline & $(0.05)$ & $(0.04)$ & $(0.03)$ & $(0.03)$ & $(0.05)$ & $(0.04)$ & $(0.04)$ \\
\hline Business/Management & 0.17 & $0.20^{* *}$ & $0.24^{* * *}$ & $0.30^{* * *}$ & $0.16^{* *}$ & $0.25^{* * *}$ & $0.24^{* * *}$ \\
\hline & $(0.09)$ & $(0.05)$ & $(0.04)$ & $(0.03)$ & $(0.05)$ & $(0.04)$ & $(0.04)$ \\
\hline Humanities/Social sciences/Arts & -0.05 & $-0.08^{*}$ & $-0.09^{* * * *}$ & $-0.11^{* * *}$ & $-0.12^{* *}$ & $-0.13^{* *}$ & $-0.10^{* *}$ \\
\hline & $(0.06)$ & $(0.03)$ & $(0.03)$ & $(0.03)$ & $(0.05)$ & $(0.04)$ & $(0.03)$ \\
\hline Social services/Education & -0.07 & $-0.13^{* * *}$ & $-0.14^{* * *}$ & $-0.16^{* * *}$ & $-0.22^{* * *}$ & $-0.24^{* * *}$ & $-0.23^{* * *}$ \\
\hline & $(0.05)$ & $(0.03)$ & $(0.03)$ & $(0.03)$ & $(0.05)$ & $(0.04)$ & $(0.03)$ \\
\hline EGP I/II technical experts & 1980 & $1985-1987$ & $1989-1991$ & 1995/1996 & 2000 & 2004-2005 & $2006-2008$ \\
\hline Ref. Science/Mathematics & & & & & & & \\
\hline Engineering/Agronomics & $0.34^{*}$ & $0.23^{* * *}$ & $0.18^{* * *}$ & 0.06 & $0.31^{* * *}$ & $0.25^{* * *}$ & $0.24^{* * *}$ \\
\hline & $(0.15)$ & $(0.05)$ & $(0.04)$ & $(0.05)$ & $(0.06)$ & $(0.05)$ & $(0.04)$ \\
\hline Business/Management & 0.06 & $-0.12^{* *}$ & $-0.27^{* * *}$ & $-0.26^{* * *}$ & $-0.19^{* * * *}$ & $-0.22^{* * *}$ & $-0.27^{* * *}$ \\
\hline & $(0.08)$ & $(0.04)$ & $(0.03)$ & $(0.03)$ & $(0.05)$ & $(0.04)$ & $(0.03)$ \\
\hline Humanities/Social sciences/Arts & 0.04 & $-0.15^{* * *}$ & $-0.28^{* * *}$ & $-0.38^{* * *}$ & $-0.30^{* * * *}$ & $-0.30^{* * * *}$ & $-0.31^{* * * *}$ \\
\hline & $(0.06)$ & $(0.03)$ & $(0.03)$ & $(0.03)$ & $(0.04)$ & $(0.04)$ & $(0.03)$ \\
\hline Social services/Education & -0.07 & $-0.21^{* * *}$ & $-0.33^{* * *}$ & $-0.36^{* * *}$ & $-0.31^{* * *}$ & $-0.33^{* * *}$ & $-0.36^{* * *}$ \\
\hline & $(0.05)$ & $(0.03)$ & $(0.03)$ & $(0.03)$ & $(0.04)$ & $(0.04)$ & $(0.03)$ \\
\hline
\end{tabular}


Tab. 6 Field of study and access to service class segments (average marginal effects). (German Microcensus, Scientific-Use-Files 1980-2008) (Continued)

\begin{tabular}{llllllll}
\hline EGP I/II social services & 1980 & $1985-1987$ & $1989-1991$ & $1995 / 1996$ & 2000 & $2004-2005$ & $2006-2008$ \\
Ref. Science/Mathematics & & & & & \\
Engineering/Agronomics & $-0.35^{*}$ & $-0.26^{* * *}$ & $-0.14^{* * *}$ & -0.04 & $-0.17^{* * *}$ & $-0.17^{* * *}$ & $-0.13^{* * *}$ \\
& $(0.16)$ & $(0.06)$ & $(0.03)$ & $(0.03)$ & $(0.04)$ & $(0.04)$ & $(0.03)$ \\
Business/Management & $-0.57^{* * *}$ & $-0.39^{* * *}$ & $-0.20^{* * *}$ & $-0.10^{* * *}$ & $-0.20^{* * *}$ & $-0.15^{* * *}$ & $-0.16^{* * *}$ \\
& $(0.10)$ & $(0.05)$ & $(0.03)$ & $(0.02)$ & $(0.03)$ & $(0.04)$ & $(0.03)$ \\
Humanities/Social sciences/Arts & 0.06 & $0.20^{* * *}$ & $0.34^{* * *}$ & $0.55^{* * *}$ & $0.37^{* * *}$ & $0.31^{* * *}$ & $0.35^{* * *}$ \\
& $(0.10)$ & $(0.04)$ & $(0.03)$ & $(0.03)$ & $(0.05)$ & $(0.04)$ & $(0.03)$ \\
Social services/Education & $0.22^{*}$ & $0.36^{* * *}$ & $0.42^{* * *}$ & $0.55^{* * *}$ & $0.51^{* * *}$ & $0.49^{* * *}$ & $0.52^{* * *}$ \\
& $(0.09)$ & $(0.04)$ & $(0.03)$ & $(0.03)$ & $(0.05)$ & $(0.04)$ & $(0.03)$ \\
\hline
\end{tabular}

Multinomial logistic regressions include main effects of nationality, HE institution and interaction terms with period; average marginal effects shown; robust standard errors in parentheses; ${ }^{*} p<0.05,{ }^{* *} p<0.01,{ }^{* * *} p<0.001$

more widespread in the population, employers may have increasing difficulties to regard a degree as reliable signal for future productivity and therefore use other signals such as the field of study. From a supply-side perspective, it was argued that due to their growing selectivity in terms of unable or less motivated students the less academically challenging fields like humanities/social sciences/arts and social services/education may increasingly be regarded as negative signals by employers. From a demand-side perspective, I additionally proposed that compositional changes in the high-skilled labour market could favour graduates from STEM fields rather than from humanities/social sciences/ arts and social services/education in terms of occupational attainment. This suggests an increasing gap in occupational attainment between humanities and social services subjects and STEM fields.

Contrary to these expectations, I further argued that this scenario may be unrealistic in the West German setting because of its occupationally segmented labour market, the moderate higher education expansion and the close match between the growing number of graduates and the upgrading of the occupational structure. Therefore, the alternative hypothesis assumes that there are no changes in the association between graduates' field of study and occupational attainment over time.

The results show that field of study differences in unemployment risk are small and do not diverge between fields over time. Tertiary graduates in West Germany continue to have a low risk of unemployment across time (Klein 2015) and this appears to be evident for graduates from all fields. In terms of access to the service class, graduates from business/management have a significantly lower probability of entering professional or managerial occupations. Over time, they were somewhat able to reduce their initial disadvantages in access to the service class. Apart from this, graduates from different fields of study do not significantly differ in access to service class positions. Moreover, graduates from humanities/social sciences/arts and so- cial services/education did not become more disadvantaged in entering the service class compared to graduates from STEM fields over time. Despite of compositional changes in the service class (relative increase of administrative and managerial positions, relative decrease of social and cultural services) they have not been increasingly pushed into inappropriate positions below the service class.

Overall, field of study differences in occupational attainment did not increase over time in West Germany supporting the alternative hypothesis $1 \mathrm{~b}$. Higher education in Germany seems to remain a good investment in terms of occupational attainment irrespective of the chosen field of study. Given that the association between graduates' social origin and field of study remained similarly constant over time (Reimer and Pollak 2010), social inequalities in occupational attainment tend to be far from increasingly transmitted via the field of study over the course of educational expansion in West Germany.

Differences between fields of study in their signalling capacity of selectivity seem to be inappropriate for explaining fields' varying labour market returns over time in West Germany. This is because signalling explanations rely on the unrealistic assumption of a unidimensional labour and job queue, in which all graduates compete for all available job vacancies. Given that fields of study have strong linkages to particular occupational segments in the West German labour market and signalling theory does not take into account labour market structures, it is unable to account for field of study differences in the labour market.

Though, the field of study may increasingly matter in countries with a massive higher education expansion or in firm internal labour markets where initial occupational placement is less determined by individuals' educational level. In line with this reasoning, field of study differences in access to the service class have been found to be stronger in the UK than in Germany (Kim and Kim 2003). Future research should therefore concentrate on a country 
with a more pronounced HE expansion and loose linkages between higher education and the labour market.

While in occupationally segmented labour markets the field of study does not appear to play a more dominant role in labour market allocation over time, other within-field differentiations indicating occupation-specific skills may have become increasingly important when graduate numbers are on the rise. For instance, Weiss et al. (2014) have shown that field-specific work experience before graduating from higher education smoothens graduates' labour market integration in Germany. It would be worthwhile to investigate whether such qualitative differences within fields matter more in terms of labour market returns than in former times.

This article concentrated on comparing field of study differences in occupational attainment among labour market entrants over time. However, while the initial placement in the labour market is decisive, graduates from different fields of study might also have, on average, different career trajectories and, further, field-specific occupational trajectories might evolve differently across periods. Future research should therefore be more concerned with both modelling career trajectories of graduates from different fields of study and how these typical career paths change under differing macrostructural conditions.

The paper is limited in considering only two labour market outcomes, risk of unemployment and access to the service class. If positions within the service class became in- creasingly heterogeneous in terms of wages over time and this growing diversity is, in turn, related to the field of study, the paper does not capture increasing field of study differences in economic returns. However, the growing wage inequalities over time have been found to be predominantly attributed to a growing gap between occupational classes, and particularly between the service class and all other classes (Giesecke and Verwiebe 2008, 2009). This suggests that the service class continues to be a strong indicator of economic returns in the labour market. Nevertheless, future studies may consider various other outcomes such as wages or being exposed to fixed-term contracts in order to provide a more coherent picture on the relationship between graduates' field of study and labour market outcomes over time.

Acknowledgements I would like to thank Walter Müller, Steffen Schindler, Martin Neugebauer, Martin Abraham and three anonymous reviewers for helpful comments on an earlier version of this article.

Funding This research received funding from the German Federal Ministry of Education and Research, grant 01JG0926.

Open Access. This article is distributed under the terms of the Creative Commons Attribution 4.0 International License (http:// creativecommons.org/licenses/by/4.0/), which permits unrestricted use, distribution, and reproduction in any medium, provided you give appropriate credit to the original author(s) and the source, provide a link to the Creative Commons license, and indicate if changes were made. 


\section{Appendix}

Tab. 7 Occupational classification in service class segments

\begin{tabular}{|c|c|c|}
\hline I/II administrative/management & I/II experts & I/II social services \\
\hline Agricultural engineer & Mechanical engineer & Physician \\
\hline Horticultural engineer & Electrical engineer & Dentist \\
\hline Forester, Gamekeeper & Building engineer & Veterinary \\
\hline Wholesaler, export merchant & Engineer for cartography & Pharmacist \\
\hline Sales director and manager in commerce & Mining engineer & Professor and related positions \\
\hline Purchasing manager & Other production engineers & Teacher for upper secondary school \\
\hline Banking expert & Industrial engineer & Humanities scholar, NES \\
\hline Advertising expert & Miscellaneous engineers & Social scientist, NES \\
\hline Agent middleman, real estate agent & Architect & Education researcher, NES \\
\hline Entrepeneur, chief executive officer, NES & Chemist, chemical engineer & Psychologist \\
\hline Division manager, assistant manager, NES & $\begin{array}{l}\text { Physicist, physical engineer, mathemati- } \\
\text { cian }\end{array}$ & Clergy \\
\hline Auditor, tax accountant and related positions & Surveying technician & Journalist \\
\hline Assistant in economic and tax law & Technician for science of management & Interpreter, translator \\
\hline Marketing and sales experts & $\begin{array}{l}\text { Biologically and technically trained as- } \\
\text { sistant }\end{array}$ & Librarian, archivist, museum guide \\
\hline Analyst, controller and related positions & $\begin{array}{l}\text { Physically and technically trained assis- } \\
\text { tant }\end{array}$ & Musician \\
\hline Executive consultant and related positions & Draftsman & Dramatic artist, singer \\
\hline Delegates, minister, electoral officials & $\begin{array}{l}\text { Architectural draftsman, mappers and } \\
\text { related pos }\end{array}$ & Graphic artist \\
\hline Executive staff in public administration & Captain (coasting and ocean shipping) & Art-related occupations \\
\hline Executive staff in associations & Technical ship officer, ship mechanist & Artiste, professional \\
\hline Head in associations, official & Scientist, NES & Natural health professional \\
\hline Upper-level civil servants & Economist, NES & $\begin{array}{l}\text { Kneader, medical bath attendant, physio- } \\
\text { therapist }\end{array}$ \\
\hline Upper-middle-level civil servants & Natural scientist, NES & Pharmacology technician \\
\hline Financial expert, accountant & Statistician, market researcher & Therapeutic occupations, NES \\
\hline Data processing expert, computer scientist, NES & Advisory and scheduling expert & Social worker, social pedagogue \\
\hline Software developer & & Remedial teacher \\
\hline Computer personnel & & Teacher, NES \\
\hline Computer marketing expert & & Teacher for lower secondary school \\
\hline Datacenter service & & Teacher for vocational school \\
\hline Other data processing experts & & Teacher for musical subjects \\
\hline Judge, prosecutor & & Sports teacher \\
\hline \multicolumn{3}{|l|}{ Law (enforcement) officer } \\
\hline \multicolumn{3}{|l|}{ Legal representative, lawyer } \\
\hline Employment adviser, career consultant & & \\
\hline
\end{tabular}

German classification KldB (Klassifizierung der Berufe) version 1975; since 1993 Microcensus KldB version 1992 (3-digits); NES not elsewhere specified 
Tab. 8 Field of study classification in major field groups

\begin{tabular}{|c|c|}
\hline Field of study groups & Subjects \\
\hline Teaching & $\begin{array}{l}\text { Teacher at Grundschule/Hauptschule, teacher at Realschule, teacher at Gymnasium, teacher at Sonder- } \\
\text { schule (special schools), teacher at Berufsschule (vocational school), sports teacher }\end{array}$ \\
\hline Law & Law \\
\hline Medicine/Pharmacology & Human medicine, dentistry, veterinary medicine, pharmacology \\
\hline Science/Technology/Mathematics & $\begin{array}{l}\text { Mathematics, statistics, computer sciences, physics, astronomy, chemistry, food chemistry, biology, bio- } \\
\text { logical chemistry, biotechnology }\end{array}$ \\
\hline Engineering/Agronomics & $\begin{array}{l}\text { Engineering sciences, mining, engine construction, electrical, engineering, traffic engineering, nautics, } \\
\text { architecture, spatial planning, construction engineering, surveying and mapping, chemical engineering, } \\
\text { environment protection, environmental technology, waste management, supply engineering, nuclear engi- } \\
\text { neering, agronomics, farming, plant production, forestry, forest and wood management }\end{array}$ \\
\hline $\begin{array}{l}\text { Business/Management/ } \\
\text { Economics }\end{array}$ & $\begin{array}{l}\text { Science of public administration, economics, business economics, tourism, marketing and promotion, } \\
\text { banking, finance and insurances, management, accounting and taxation, engineering economics, security } \\
\text { management }\end{array}$ \\
\hline $\begin{array}{l}\text { Humanities/Social Sciences/ } \\
\text { Arts }\end{array}$ & $\begin{array}{l}\text { Christian theology, other religious studies, philosophy, history, librarianship, media studies, journal- } \\
\text { ism, linguistics, cultural sciences, classical philology, German language and literature studies, anglis- } \\
\text { tics, American studies, romance studes, slavic studies, extra-European lingustics, political science, social } \\
\text { sciences, sociology, psychology, geography, art history, aesthetics, visual arts, performing arts, film and } \\
\text { television, music, musicology, design, interior architecture, audiovisual techniques and media }\end{array}$ \\
\hline Social services/Education & $\begin{array}{l}\text { Social welfare services, social work, social pedagogy, therapeutic pedagogy, nursing science, nutrition } \\
\text { science, health management, educational science }\end{array}$ \\
\hline
\end{tabular}

\section{References}

Acemoglu, D.: Technical Change, Inequality and the Labor Market. J Econ Lit 40, 7-72 (2002)

Arcidiacono, P.: Ability Sorting and the Returns to College Major. J Econom 121, 343-375 (2004)

Autor, D.H., Katz, L.F., Krueger, A.B.: Computing Inequality: Have Computers Changed the Labor Market? Q J Econ 113, 1169-1213 (1998)

Becker, M., Trautwein, U., Lüdtke, O., Cortina, K.S., Baumert, J.: Bildungsexpansion und kognitive Mobilisierung. In: Hadjar, A., Becker, R. (eds.) Die Bildungsexpansion: Erwartete und unerwartete Folgen, pp. 63-89. (2006)

Bobbitt-Zeher, D.: The Gender Income Gap and the Role of Education. Sociol Educ 80, 1-22 (2007)

Brown, C., Corcoran, M.E.: Sex-based Differences in School Content and the Male-Female Wage Gap. J Labor Econ 15, 431-465 (1997)

Clark, B.R.: Academic Differentiation in National Systems of HigherEducation. Comp Educ Rev 22(2), 242-258 (1978)

Davies, S., Guppy, N.: Fields of Study, College Selectivity and Student Inequalities in Higher Education. Soc Forces 75, 1417-1438 (1997)

Daymont, T.N., Andrisani, P.J.: Job Preferences, College Major, and the Gender Gap in Earnings. J Hum Resour 19, 408-428 (1984)

Dörfler, L., Werfhorst, H.G. Van de: Employers' Demand for Qualifications and Skills: Increased Merit Selection in Austria, 1985-2005. Eur Soc 11, 697-721 (2009)

Erikson, R., Goldthorpe, J.H.: The Constant Flux. A Study of Class Mobility in Industrial Societies. Clarendon Press, Oxford (1992)

Gangl, M.: Explaining Change in Early Career Outcomes: Labour Market Conditions, Educational Expansion, and Youth Cohort Sizes. In: Müller, W., Gangl, M. (eds.) Transitions from Education to Work in Europe: The Integration of Youth into EU Labour Markets, pp. 251-276. Oxford University Press, Oxford (2003a)

Gangl, M.: The Structure of Labour Market Entry in Europe: A Typological Analysis. In: Müller, W., Gangl, M. (eds.) Transitions from Education to Work in Europe: The Integration of Youth into
EU Labour Markets, pp. 107-128. Oxford University Press, Oxford $(2003 b)$

Gebel, M., Pfeiffer, F.: Educational Expansion and its Heterogeneous Returns for Wage Workers ZEW Discussion Paper, vol. 07-010. (2007)

Gerber, T.P., Cheung, S.Y.: Horizontal Stratification in Postsecondary Education: Forms, Explanations, and Implications. Annu Rev Sociol 34, 299-318 (2008)

Gerber, T.P., Schaefer, D.R.: Horizontal Stratification of Higher Education in Russia: Trends, Gender Differences, and Labor Market Outcomes. Sociol Educ 77, 32-59 (2004)

Gerhart, B.: Gender Differences in Current and Starting Salaries - The Role of Performance, College Major and Job Title. Ind Labor Relations Rev 43, 418-433 (1990)

Giesecke, J., Schindler, S.: Field of Study and Flexible Work: A Comparison between Germany and the UK. Int J Comp Sociol 49, 283-304 (2008)

Giesecke, J., Verwiebe, R.: Die Zunahme der Lohnungleichheit in der Bundesrepublik - Aktuelle Befunde für den Zeitraum von 1998 bis 2005. Kolner Z Soz Sozpsychol 37, 403-422 (2008)

Giesecke, J., Verwiebe, R.: Wachsende Lohnungleichheit in Deutschland. Qualifikations- und klassenspezifische Determinanten der Entlohnung zwischen 1998 und 2006. Berl J Soziol 19, 531-555 (2009)

Glebbeek, A., Wim, N., Schakelaar, R.: The Labor-Market Position of Dutch Sociologists - An Investigation Guided by a Theoretical Model. Neth J Soc Sci 25, 57-74 (1989)

Goldthorpe, J.H., McKnight, A.: The Economic Basis of Social Class. In: Morgan, S.L., Grusky, D.B., Fields, G.S. (eds.) Mobility and Inequality: Frontiers of Research in Sociology and Economics, pp. 109-136. Stanford University Press, Stanford (2006)

Grotheer, M., Isleib, S., Netz, N., Briedis, K.: Hochqualifiziert und Gefragt. Ergebnisse der zweiten HIS-HF Absolventenbefragung des Jahrgangs 2005. His: Forum Hochsch 14, (2012)

Hansen, M.N.: Education and Economic Rewards. Variations by Social-Class Origin and Income Measures. Eur Sociol Rev 17, 209-231 (2001) 
Heijke, H., Meng, C., Ramaekers, G.: An Investigation into the Role of Human Capital Competences and their Pay-off. Int J Manpow 24, 750-773 (2003)

Hillmert, S., Jacob, M.: Multiple Episodes: Training Careers in a Learning Society Globalife Working Paper, vol. 64. OttoFriedrich Universität Bamberg, Bamberg (2004)

International Labour Office (ILO): Statistical sources and methods, iii: Economically active population, employment, unemployment and hours of work (household surveys, 3rd edn.), ILO, Geneva (2005)

Ishida, H., Spilerman, S., Su, K.-H.: Educational Credentials and Promotion Chances in Japanese and American Organizations. Am Sociol Rev 62, 866-882 (1997)

Jackson, M., Goldthorpe, J.H., Mills, C.: Education, Employers and Class Mobility. Res Soc Stratif Mobil 23, 3-33 (2005)

Kim, A., Kim, K.-W.: Returns to Tertiary Education in Germany and the UK: Effects of Fields of Study and Gender. Mzes Work Pap 62, (2003)

Klein, M.: Higher Education and Non-Pecuniary Returns in Germany: Tracing the Mechanisms behind Field of Study Effects at the Start of the Career. Ir Educ Stud 30, 247-264 (2011a)

Klein, M.: Trends in the Association Between Educational Attainment and Class Destinations in West Germany: Looking Inside the Service Class. Res Soc Stratif Mobil 29, 427-444 (2011b)

Klein, M.: The Increasing Unemployment Gap Between the Low and High Educated in West Germany: Structural or Cyclical Crowding-out. Soc Sci Res 50, 110-125 (2015)

Kriesi, I., Buchmann, M., Sacchi, S.: Variation in Job Opportunities for Men and Women in the Swiss Labor Market 1962-1989. Res Soc Stratif Mobil 28, 309-323 (2010)

Leuze, K.: What Makes for a Good Start? Consequences of Occupation-Specific Higher Education for Career Mobility. Int. J. Sociol., 37, 29-53 (2007)

Lucas, S.R.: Effectively Maintained Inequality: Education Transitions, Track Mobility, and Social Background Effects. Am J Sociol 106, 1642-1690 (2001)

Marsden, D.: Institutions and Labour Mobility: Occupational and Internal Labour Markets in Britain, France, Italy and West Germany. In: Brunetta, R., Dell'Aringa, C. (eds.) Labour Relations and Economic Performance, pp. 414-438. The Macmillan Press, Venedig (1990)

Mitra, A.: Mathematics Skill and Male-Female Wages. J Socio-economics 31, 443-456 (2002)

Mood, C.: Logistic Regression: Why We Cannot Do What We Think We Can Do, and What We Can Do About It. Eur Sociol Rev 26, 67-82 (2010)

Müller, W., Wolbers, M.H.J.: Educational Attainment in the European Union: Recent Trends in Qualification Patterns. In: Müller, W., Gangl, M. (eds.) Transitions from Education to Work in Europe: The Integration of Youth into EU Labour Markets, pp. 23-62. Oxford University Press, Oxford (2003)

Murnane, R.J., Willett, J.B., Levy, F.: The Growing Importance of Cognitive Skills in Wage Determination. Rev Econ Stat 77, 251-266 (1995)

Noelke, C., Gebel, M., Kogan, I.: Uniform Inequalities: Institutional Differentiation and the Transition from Higher Education to Work in Post-socialist Central and Eastern Europe. Eur Sociol Rev 28, 704-716 (2012)

OECD: Education at a Glance. OECD, Paris (2013)

Oesch, D., Rodríguez, M.J.: Upgrading or Polarization? Occupational Change in Britain, Germany, Spain and Switzerland, 1990-2008. Socioecon Rev 9, 503-532 (2011)

Paglin, M., Rufolo, A.: Heterogeneous Human Capital, Occupational Choice and Male-Female Earnings Differences. J Labor Econ 8, 123-144 (1990)

Reimer, D., Noelke, C., Kucel, A.: Labor Market Effects of Field of Study in Comparative Perspective: An Analysis of 22 European Countries. Int J Comp Sociol 49, 233-256 (2008)
Reimer, D., Pollak, R.: Educational Expansion and Its Consequences for Vertical and Horizontal Inequalities in Access to Higher Education in West Germany. Eur Sociol Rev 26, 415-430 (2010)

Reimer, D., Steinmetz, S.: Highly Educated but in the Wrong Field? Educational Specialisation and Labour Market Risks of Men and Women in Spain and Germany. Eur Soc 11, 723-746 (2009)

Roksa, J.: Double Disadvantage or Blessing in Disguise? Understanding the Relationship between College Major and Employment Sector. Sociol Educ 78, 207-232 (2005)

Shauman, K.A.: Occupational Sex Segregation and the Earnings of Occupations: What Causes the Link among College-Educated Workers? Soc Sci Res 35, 577-619 (2006)

Sørensen, A.B., Kalleberg, A.L.: An Outline of a Theory of Matching Persons to Jobs. In: Berg, I. (ed.) Sociological Perspectives on the Labor Market, pp. 49-74. Academic, New York (1981)

Spence, M.: Job Market Signaling. Q J Econ 87, 355-374 (1973)

Stiglitz, J.E.: The Theory of Screening, Education, and the Distribution of Income. Am Econ Rev 65, 283-299 (1975)

Thurow, L.C.: Generating Inequality. Basic Books, New York (1975)

Werfhorst, H.G. Van de: Fields of Study, Acquired Skills and the Wage Benefit from a Matching Job. Acta Sociol 45, 287-303 (2002)

Werfhorst, H.G. Van de: Systems of Educational Specialization and Labor Market Outcomes in Norway, Australia, and The Netherlands. Int J Comp Sociol 45, 315-335 (2004)

Werfhorst, H.G. Van de, Kraaykamp, G.: Four Field-Related Educational Resources and Their Impact on Labor, Consumption, and Sociopolitical Orientation. Sociol Educ 74, 296-317 (2001)

Walker, I., Zhu, Y.: The College Wage Premium, Overeducation and the Expansion of Higher Education in the UK IZA Discussion Paper, vol. 1627. (2005)

Weiss, F., Klein, M., Grauenhorst, T.: The Effects of Work Experience During Higher Education on Labour Market Entry: Learning By Doing or An Entry Ticket? Work Employ Soc 28(5), 788-807 (2014)

Wolbers, M.H.J.: Job Mismatches and Their Labour-Market Effects among School-Leavers in Europe. Eur Sociol Rev 19, 249-266 (2003)

Markus Klein is Lecturer for Human Development and Education Policy at the University of Strathclyde. Previously, he was a Research Fellow in the 'Education and Social Stratification' strand of the Applied Quantitative Methods Network (AQMeN) at the University of Edinburgh. He was awarded his $\mathrm{PhD}$ in Sociology from the Graduate School of Economic and Social Sciences (GESS), University of Mannheim. His main research interests include social stratification, sociology of education, labour market sociology, and child development 